\title{
O wstydzie na lekcjach języka polskiego
}

\author{
Magdalena Grzybek \\ Szkoła Podstawowa nr 2 w Kórniku
}

Żyjemy obecnie w czasach, w których, jak z pozoru mogłoby się wydać, nie przywiązuje się wagi do wstydu. Patrząc na współczesną modę, zachowania, można by pokusić się o stwierdzenie, że mamy wręcz do czynienia z kulturą bezwstydu. Ciekawe wydaje się określenie Anny Król-Kuczkowskiej, która mówi: „Stajemy się czymś w rodzaju bezwstydnej kultury wstydu”. Oznacza to, że wstyd jest bardzo głęboko zakorzeniony, zarówno w ludziach dorosłych, jak i młodych, a to, co prezentujemy na zewnątrz, stanowi próbą ukrycia tego, o czym nie chcemy mówić. Temat wydaje się ważny, bo dotyczy każdego z nas: „badanie wstydu w nieunikniony sposób często konfrontuje nas z własnymi doświadczeniami wstydu. Wstydzimy się przecież wszyscy, ale nikt o tym nie mówi” ${ }^{2}$. Dlatego warto przerwać milczenie i zmierzyć się z tą problematyką na lekcjach języka polskiego w odniesieniu do bohaterów literackich oraz doświadczeń uczniów. Warto porozmawiać z nimi o emocjach, pokazać, jakie korzyści może przynieść świadomość własnych słabości i przezwyciężanie związanego z nimi wstydu.

\section{Zacznijmy od bohaterów literackich}

Punktem wyjścia cyklu lekcji dotyczących wstydu, zrealizowanych przeze mnie w szkole podstawowej, stała się postać Pijaka z Małego Księcia Antoine'a de Saint-Exupéry'ego. Podczas rozmowy z głównym bohaterem mówi on, że pije dlatego, że jest mu wstyd, że pije ${ }^{3}$. Nie widzi wyjścia z sytuacji, w której się znalazł, bo emocja, która mu towarzyszy, pochłonęła go całkowicie. Uczniowie bardzo często twierdzili, że jego zachowanie nie ma sensu i określali je jako „błędne koło”. Wielu z nich mówiło, iż żal im tego

${ }^{1}$ Schowani w sobie. Rozmowa z Anna Król-Kuczkowska, 2019, w: Jucewicz A., Czujac. Rozmowy o emocjach, Warszawa, s. 216.

2 Tamże, s. 203.

${ }^{3}$ Saint-Exupéry de A., 2005, Mały Książę, Toruń, s. 37. 
bohatera, podobnie jak Małemu Księciu. Inni wręcz złościli się i twierdzili, że sam wybiera taki los, jest słaby, wstyd odebrał mu siłę do działania.

Kolejnym elementem było przyjrzenie się innym bohaterom literackim, którzy doświadczali wstydu. Aby zmotywować uczniów do pracy, przygotowałam quiz. Na tablicy multimedialnej widoczny był fragment tekstu lub zdjęcie bohatera z realizacji filmowej. Uczniowie odgadywali, o kogo chodzi lub podawali przykład sytuacji, w której postać doświadczyła wstydu. Pojawili się tacy bohaterowie jak: Nika z powieści Rafała Kosika Felix, Net i Nika oraz Gang Niewidzialnych Ludzi (wstyd związany z sytuacją materialną), Ebenezer Scrooge z Opowieści wigilijnej Charlesa Dickensa (wstyd związany ze słowami, które mówił, i tym, jak się zachowywał), Staś z W pustyni i w puszczy Henryka Sienkiewicza (wstyd z powodu tego, że zostali porwani z Nel, a on nic nie mógł zrobić), Bilbo Baggins, czyli tytułowy hobbit (wstyd, że nie sprosta oczekiwaniom, które mieli wobec niego uczestnicy wyprawy), wreszcie biblijne postacie Adama i Ewy (wstyd z powodu nagości). Następnie uczniowie zostali podzieleni na grupy, a ich zadaniem było ustalenie, komu z przedstawionych bohaterów udało się pokonać uczucie wstydu i jakie były tego konsekwencje.

Ustalenia analityczno-interpretacyjne zostały zebrane w tabeli i przestawiały się następująco:

\begin{tabular}{|c|c|c|}
\hline Bohater & $\begin{array}{c}\text { Czy } \\
\text { pokonał } \\
\text { wstyd? }\end{array}$ & Konsekwencje \\
\hline Pijak & NIE & Nadal pije, niszczy swoje zdrowie, marnuje życie. \\
\hline Nika & TAK & $\begin{array}{l}\text { Bohaterka zaprosiła Felixa i Neta do swojego mieszkania, } \\
\text { przyjaciele nie odrzucili jej z powodu sytuacji materialnej, } \\
\text { wspierali ją. Przestała się wstydzić, zyskała prawdziwą } \\
\text { przyjaźń. }\end{array}$ \\
\hline $\begin{array}{l}\text { Ebenezer } \\
\text { Scrooge }\end{array}$ & TAK & $\begin{array}{l}\text { Scrooge wstydził się słów, które wypowiedział, } \\
\text { dotyczących na przykład tego, że niektórzy ludzie powinni } \\
\text { umrzeć, zmniejszając w ten sposób nadmiar ludności na } \\
\text { świecie. Wstydził się także swojego zachowania. Zmienił } \\
\text { swoje życie, stał się dobrym, hojnym człowiekiem. }\end{array}$ \\
\hline Staś & TAK & $\begin{array}{l}\text { Zrozumiał, że nie ma wpływu na sytuację, w której się } \\
\text { znalazł z Nel. Wstydził się tego, że wcześniej mówił, jaki } \\
\text { jest odważny i że poradziłby sobie z każdym. Spokorniał, } \\
\text { a w odpowiednim momencie zabił lwa i uwolnił z rąk } \\
\text { porywaczy siebie i przyjaciółkę. }\end{array}$ \\
\hline Bilbo & TAK & $\begin{array}{l}\text { Obawiał się tego, że mogłoby się wydać, że nie jest } \\
\text { prawdziwym włamywaczem. Spowodowało to, że zmienił } \\
\text { się w odważnego hobbita - próbował okraść trolle, walczył } \\
\text { z pająkami, uwolnił towarzyszy z więzienia u elfów, wszedł } \\
\text { do skarbca, w którym był smok. }\end{array}$ \\
\hline $\begin{array}{l}\text { Adam } \\
\text { i Ewa }\end{array}$ & TAK & Wstydzili się, że są nadzy, więc okryli się. \\
\hline
\end{tabular}


Po zebraniu tych ustaleń, uczniowie zwrócili uwagę, że pokonanie wstydu przyniosło bohaterom sporo korzyści: zyskali nowe doświadczenia, zmienili swoje życie, nie musieli niczego ukrywać przed ważnymi dla nich osobami. Nieco inaczej poradzili sobie ze wstydem Adam i Ewa - nie pokonali tak jak inni, ale znaleźli sposób, aby sobie z nim poradzić. Jedynym przegranym zostaje Pijak, który nie podjął żadnych działań.

\section{„Schowani w sobie”, czyli wstyd w świecie rzeczywistym}

Kolejna lekcja poświęcona została analizie wywiadu z Anną Król-Kuczkowską. Rozmowa dotyczyła destrukcyjnego wpływu wstydu. Autorka odróżniła poczucie winy, które powoduje, że chcemy naprawić sytuację, od wstydu, sprawiającego, że zamykamy się w sobie, wycofujemy ze świata: „Nie ma miejsca na: przepraszam, porozmawiajmy, czy mógłbym ci to wyna-

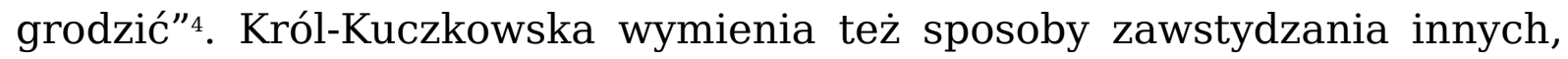
np. spojrzenie, gest, upokarzanie, obrażanie, ale też milczenie. Zauważa również, że istnieje „zdrowy wstyd”, którego współcześnie zaczyna ludziom brakować, a który świadczy o naszej dojrzałości, poczuciu odpowiedzialności oraz przywiązaniu do granic i intymności. Wywiad posłużył jako dodatkowy komentarz do sytuacji, w jakich znaleźli się bohaterowie literaccy. Zanim jednak do tego doszło, uczniowie mierzyli się z tekstem samodzielnie, odpowiadając na pytania dotyczące znaczenia tytułu wywiadu oraz wspomnianej różnicy pomiędzy poczuciem winy a wstydem. Porządkowali też informacje dotyczące wiadomości pojawiających się w kolejnych akapitach tekstu, zastanawiali się, dlaczego wstyd jest potrzebny, wyjaśniali, jak rozumieją wyrażenie: „bezwstydna kultura wstydu”, a także tworzyli wpis, który mógłby się pojawić na forum internetowym. To ostatnie zadanie miało szczególne znaczenie, ponieważ dotyczyło tego, czego wstydzą się współcześnie młodzi ludzi. Należało tutaj podać przynajmniej dwa przykłady i wyjaśnić, dlaczego właśnie to jest powodem do wstydu.

\section{Co można zrobić?}

Wszystkie odpowiedzi uczniów zawarte we wspomnianym powyżej ćwiczeniu zostały zebrane i zaprezentowane podczas kolejnych zajęć w formie mapy myśli. Okazało się, że młodzi ludzie wstydzą się braku pieniędzy, tego, że są inni od pozostałych, swojego ciała, tego, co robią w internecie, negatywnej oceny innych osób, tego, że są gorsi w nauce od innych, przekonań religijnych, zdjęć zamieszczanych w internecie bez ich wiedzy i zgody, wyrażania własnego zdania, a wreszcie wystąpień publicznych i odpowiadania na forum klasy5.

\footnotetext{
${ }^{4}$ Schowani $w$ sobie..., s. 204.

${ }^{5}$ Wszystkie odpowiedzi i fragmenty prac pochodzą od uczniów klas VII Szkoły Podstawowej nr 2 w Kórniku.
} 


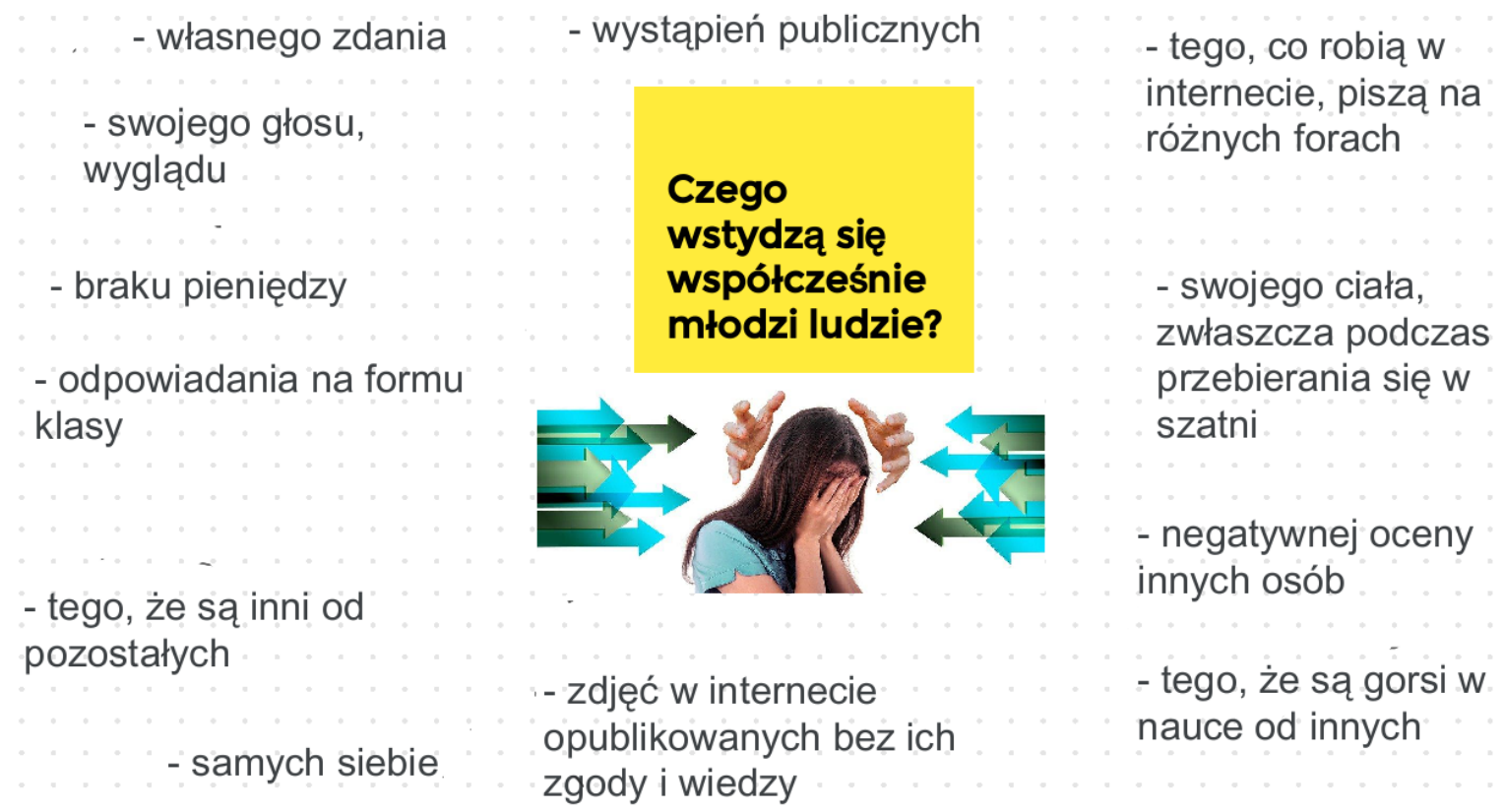

Po przedstawianiu swoich sądów uczniowie zostali podzieleni na grupy. Każda z nich przez 10 minut pracowała nad ustaleniem tego, co musiałoby się stać, aby młodzi ludzie przestali się wstydzić danej rzeczy, oraz nad tym, jakie korzyści przynosi przezwyciężenie wstydu. Propozycje uczniów zostały zapisane i przedyskutowane. Okazało się, że walka ze wstydem może być trudna, ale pokonanie go daje wiele korzyści, np. zwiększa pewność siebie, pozwala na większy dystans do własnej osoby, wywołuje dumę z tego, jakim się jest, ale też motywuje do stawania się lepszym, „prawdziwszym”.

\section{Czy warto podjąć wysiłek?}

Kolejna część cyklu została zaprojektowana w taki sposób, aby uczniowie w praktyczny sposób mogli zmierzyć się z wstydem związanym z wystąpieniami publicznymi, a $\mathrm{w}$ tym przypadku $\mathrm{z}$ przemawianiem na forum klasy. Umiejętność ta jest bardzo ważna, a wiele osób odczuwa ogromną tremę z tego powodu. Warto zauważyć, iż w podstawie programowej dla szkoły podstawowej wymaga się od ucznia, by potrafił napisać przemówienie, umiał argumentować, wyrażać własne zdanie ${ }^{6}$. Nauczyciel języka polskiego, w myśl sformułowanych w tym dokumencie zapisów, ma uczyć również sztuki komunikacji, wyrażania własnych myśli, wprowadzać elementy retoryki i wychować świadomego użytkownika języka. We współczesnym świecie to właśnie te umiejętności, określane jako miękkie, mają również ogromne znaczenie na rynku pracy.

${ }^{6}$ Podstawa programowa z języka polskiego dla szkoły podstawowej: III. 1.1) 4) 6) 2. 1). 


\section{Pokonać wstyd - piszemy przemówienie}

Pod kierunkiem nauczyciela uczniowie wyodrębniali poszczególne elementy przemówienia (zwrot do adresata, wstęp z tezą, argumenty, zakończenie), przypominali również, w jaki sposób powinien być zbudowany argument, a także wskazywali środki językowe właściwe dla tej formy wypowiedzi - np. bezpośrednie zwroty do adresatów. Na koniec otrzymali kartkę z „bankiem słownictwa”, z którego mogli korzystać podczas pisania przemówienia.

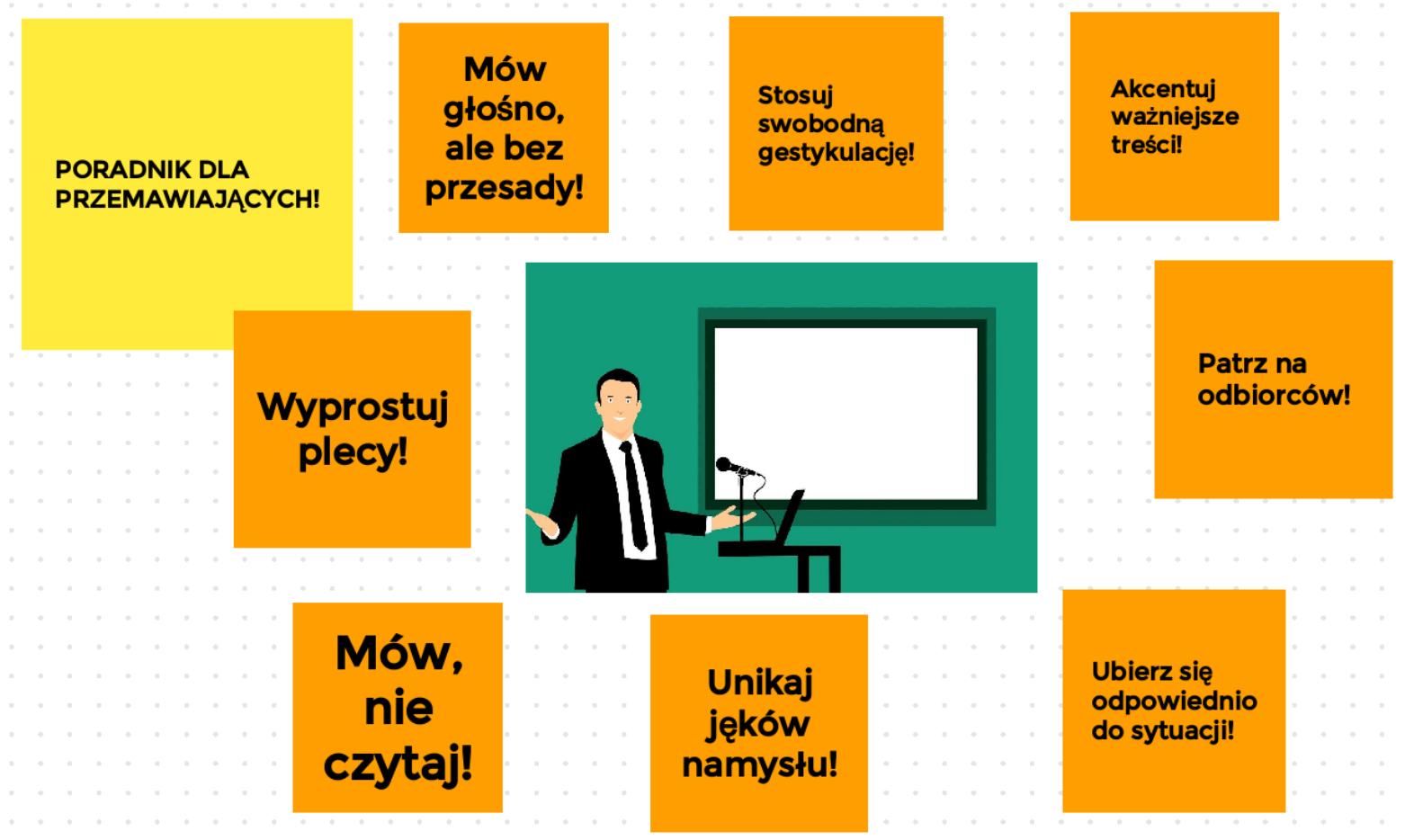

Zanim jednak do tego doszło, wykonywali ćwiczenia redakcyjne, które zaczynały się od analizy różnych tematów, pisania wstępów z tezą, argumentacji i zakończenia. Następnie wyniki pracy prezentowali na forum, a pozostałe osoby wskazywały to, co wykonane było dobrze i ewentualne elementy wymagające dopracowania. Po analizie przykładu mowy przekonującej rówieśników do tego, że warto czytać książki (zamieszczonego w Informatorze o egzaminie ósmoklasisty z języka polskiego od roku szkolnego 2018/20197) i ćwiczeniach redakcyjnych uczniowie otrzymali polecenie nawiązujące do lekcji o wstydzie: Napisz przemówienie skierowane do rówieśników, w którym przekonasz ich, że warto pokonać wstyd. W swojej pracy przywołaj wybrana postać literacka $z$ lektury obowiazkowej oraz przykład $z$ własnego życia lub innych młodych ludzi. Twoja praca powinna mieć minimum 200 słów.

${ }^{7}$ https://cke.gov.pl/images/_EGZAMIN_OSMOKLASISTY/Informatory/Informator_P1 polski.pdf (dostęp z dnia 6.07.2021). 
Poniżej prezentuję - poddaną lekkiej redakcji, ale z zachowaniem oryginalnej pisowni - wybraną pracę uczniowską:

Drogie Koleżanki, drodzy Koledzy!

Spotkaliśmy się dzisiaj po to, aby porozmawiać na temat wstydu i odpowiedzieć na pytanie, czy warto pokonać swój wstyd? Na początek musimy odpowiedzieć sobie na pytanie, czym jest wstyd? Wstyd to przykre uczucie spowodowane niewłaściwym postępowaniem. Wstyd, który odczuwamy, ma ogromny wpływ na nasze życie. Wstyd pojawia się za każdym razem, gdy czegoś nie zrobiliśmy lub zrobiliśmy coś, co nie spełniło naszych oczekiwań lub naszych bliskich. (...) Wstydzimy się mówić o tym co dla nas jest wstydliwe. Przeżywając wstyd, doświadczamy osamotnienia. Strach przed wstydem popycha nas do wielu niewłaściwych zachowań, takich jak uzależnienie, choroby. Człowiek przeżywający wstyd wycofuje się z kontaktu $\mathrm{z}$ innym człowiekiem, milczy. Inni usprawiedliwiają się lub też reagują na wstyd agresją. Wyładowują swoje złe emocje na innych. Chciałbym Was dzisiaj przekonać do tego, że warto pokonać wstyd.

Możemy wstydzić się z wielu powodów. Każdy z nas na co dzień doświadcza uczucia wstydu. Wstydzimy się tego, że nie mamy markowych ubrań, nowego modelu telefonu. Wielu z nas nie włącza kamerki podczas lekcji, ponieważ wstydzi się tego, że ma za skromnie urządzony pokój, czy też źle wygląda i może zostać przez innych wyśmiany. Myślę, że warto pokonać swój wstyd, ponieważ uczy nas to radzenia sobie z naszymi emocjami. Przyznanie się do wstydu świadczy o naszej dojrzałości i świadomości tego, co przeżywamy.

Zachowanie bohaterki książki pod tytułem „Felix, Net i Nika oraz Gang Niewidzialnych Ludzi" pokazuje nam, jak można pokonać swój wstyd. Jedna z głównych bohaterek o imieniu Nika miała kiepską sytuację materialną, której się wstydziła. Niektóre dziewczyny traktowały ją trochę jak dziwadło. Nika nie nosiła, tak jak one, różowych bluzeczek, modnych butów i torebeczek. Nie była tak całkiem trendy. Miała swój styl, który był wynikiem jej kiepskiej sytuacji materialnej. Była z tego powodu ośmieszana przez rówieśników, a to powodowało, że wstydziła się swojej sytuacji. Jako jedyna podczas wyjazdu w góry nie miała stroju narciarskiego, gdy inni mieli nieprzemakalne kurtki i spodnie. Koleżanka Niki wyśmiewała się z niej, że jeździ na nartach w jeansach. Kpiącym tonem pytała Nikę, czy na śmietniku nie leżały żadne spodnie narciarskie?. Nika skrywała w sobie tajemnicę, opowiadała, że mieszka z tatą, który tak naprawdę od dwóch lat nie żył. Utrzymywała się z jego renty (...). Bała się wyjawić prawdę, żeby nie wysłali jej do domu dziecka. Nika w końcu odważyła się i pokonała swój wstyd, opowiadając o swojej sytuacji swoim przyjaciołom, Netowi i Feliksowi. Została przez nich wysłuchana i zrozumiana, nie zmieniło to ich relacji.

Tylko wtedy, gdy będziecie odważni, wstyd Was nie pokona. Należy być szczerym i znaleźć w sobie odwagę mówienia o wstydzie. Tylko wówczas, gdy głośno o nim opowiecie, wstyd przestaje mieć nad nami władzę. Najlepszym sposobem walki ze wstydem jest podzielenie się z kimś swoją historią. Nie ukrywajcie wstydu, rozmawiajcie o nim!

(Antoni)

Polonistyka. Innowacje

Numer 14, 2021 


\section{Czas na przemowę!}

Zanim uczniowie wygłosili przemówienie, analizowali, w jaki sposób należy to robić. Motto stanowić mogą tutaj słowa wypowiedziane przez profesora Jerzego Bralczyka podczas przemówienia „Jak mówić, żeby nas słuchano”: „Dobrze jest, jeżeli satysfakcja mówiącego nie przewyższa satysfakcji słuchającego" ${ }^{\prime}$, co oznacza, że zawsze powinniśmy mieć na uwadze odbiorcę, do którego się zwracamy.

Kolejna lekcja poświęcona została więc na przeanalizowanie przykładowej mowy i omówienie komunikacji niewerbalnej. W tym celu wykorzystałam krótkie przemówienie z filmu w reżyserii Petera Jacksona Władca pierścieni. Powrót króla. Wygłasza je jeden z głównych bohaterów - Aragorn, do swojego wojska, które stoi u bram twierdzy Saurona i za chwilę ma zmierzyć się z armią ciemności Fragment ten, jak również kontekst, w którym mowa została wygłoszona, były znane uczniom. Bez większych kłopotów zauważyli, że bohater jest bardzo dynamiczny, porusza się podczas mówienia, aby wszyscy go mogli widzieć i słyszeć, wymachuje mieczem, mówi głośno i wyraźnie, jego postawa wyraża pewność siebie. Świadomie odwołuje się też do emocji, aby zachęcić do walki. Ostatecznie udaje mu się zmotywować żołnierzy do bitwy.

Na lekcji bezpośrednio przygotowującej do wygłoszenia przemówienia warto zaprezentować także różne postawy, które pojawiają się u mówiących i zastanowić się wspólnie nad tym, w jaki sposób wpływają one na odbiór wypowiedzi. Chodzi tutaj przede wszystkim o zwrócenie uwagi na postawę (zgarbione i wyprostowane plecy), utrzymywanie kontaktu wzrokowego $\mathrm{z}$ odbiorcą, gestykulację, które pomaga $\mathrm{w}$ wypowiedzi, ale nie powinna być przesadzona i sztuczna, głośność mówienia, tempo wypowiedzi itd. Jak pisze Mateusz Grzesiak: „To, co zebrani dostrzegą w twojej postawie - usłyszą w twoim głosie i odczują we wszystkim, co robisz" ${ }^{\prime \prime}$. Ważne jest unikanie również tzw. jęków namysłu, nad którymi bardzo często trudno jest mówiącym zapanować, oraz zadbanie o wygląd: „Pierwsze wrażenie, zwłaszcza jeśli występuje się tylko raz, może też być jedynym, jakie mamy okazję zrobić (...). Dobrze jest zadbać o to, by postrzegano nas w sposób ułatwiający skuteczne wywierania wpływu, czyli jako człowieka estetycznego, a tym samym inteligentnego (czyt. godnego zaufania) ${ }^{10}$ ". Analiza tych kwestii zakończyła się utworzeniem przez uczniów poradnika dla przemawiających, w którym umieszczone zostały najważniejsze wskazówki związane z komunikacją niewerbalną.

\footnotetext{
${ }^{8}$ Wykład został wygłoszony 3 kwietnia 2017 roku w ramach cyklu wykładów interdyscyplinarnych „Wielkie pytania w nauce” w Wyższej Szkole Informatyki i Zarządzania z siedzibą w Rzeszowie. Można wysłuchać go z uczniami i wypisać najważniejsze tezy albo zachęcić do samodzielnego wysłuchania https://www.youtube.com/watch?v=TG4ZAGnlPOY (dostęp z dnia 6.07.2021).

${ }_{9}^{9}$ Grzesiak M., 2017, Psychologia nauczania, czyli jak skutecznie prowadzić szkolenia, zarzadzać grupami i występować przed publicznościa, Gliwice, s. 59.

${ }^{10}$ Tamże, s. 36.
} 


\section{„Poetae nascuntur, oratores fiunt" - poetą trzeba się urodzić, mówcą można się stać}

Uczniowie wyposażeni w odpowiednią wiedzę, przystąpili do wygłaszania przemówień, które wcześniej zostały sprawdzone i tam, gdzie było to koniecznie, poprawione. W związku z tym, że było to ich pierwsze wystąpienie, nie zawsze było ono bardzo dobre, dlatego szczególne znaczenie miało tutaj pozytywne wzmocnienie i możliwość ponownego wygłoszenia przemowy w razie niepowodzenia lub zbyt dużej tremy, tym bardziej, że niektóre miały charakter bardzo osobisty, o czym przekonuje następujący przykład:

Mój pierwszy argument odnosi się do sytuacji, gdy musiałam zmienić z szkołę, w której się ze mnie śmiano przez to, że byłam biedna i nie mogłam sobie pozwolić na drogie ubrania, buty wyjścia do kina itp. Zmieniłam szkołę na inną. Na szczęście była blisko mojego domu. Wstydziłam się tam iść, bo myślałam, że powtórzy się sytuacja. Okazało się jednak, że ludzie byli tam bardzo mili. Po dwóch miesiącach znalazłam sobie przyjaciółkę, której nie przeszkadzało to, że pochodzę z biedniejszej rodziny. Po jakimś czasie nawet zaprosiłam ją do domu, miałam swoją grupę znajomych. Czułam się dobrze, cieszyłam się z tego, że podjęłam taką decyzję i teraz myślę, że mogłam się nie wstydzić tak bardzo mojej sytuacji rodzinnej, ponieważ dobrze się czuję z tym, gdzie mieszkam i wiem, że rodzina mnie kocha.

Wygłaszanie przemówień było ostatnim elementem całego cyklu związanego ze wstydem. Uczniowie mogli sprawdzić tę umiejętność oraz zmierzyć się z własnymi ograniczeniami. Po zakończeniu lekcji stwierdzili, że było to ciekawe doświadczenie, które może przydać im się w przyszłości, a poruszane tematy były ważne oraz bliskie ich doświadczeniom i skłaniały do myślenia. Być może wstyd nie jest popularnym tematem w szkole, ale namysł nad nim okazuje się bardzo potrzebny w dzisiejszych czasach, gdzie za wszelką cenę ludzie starają się udowodnić, że nie istnieje. Tymczasem bardzo mocno towarzyszy nam w codziennym życiu i warto mieć świadomość, kiedy jest potrzebny, a kiedy można go przezwyciężyć.

\section{O Autorce:}

Magdalena Grzybek - absolwentka Uniwersytetu im. Adama Mickiewicza w Poznaniu; nauczycielka języka polskiego w Szkole Podstawowej nr 2 w Kórniku, od 11 lat związana ze szkolnictwem. Współpracowała z „Polonistyką" oraz Instytutem Badań Edukacyjnych. 